\title{
The Role of Team Sports Curriculum and its Teachers on Acquiring Citizenship Values for Third Year Female Students (Methods of Teaching Branch) of Faculty of Physical Education
}

\author{
BY \\ Dr. Zinab Ismail Mohamed, Faiza Mohamed Shebl, Fatem Ahmed Basiouny \\ Handball Department of Team and Racquet Sports, Faculty of Physical Education- \\ Tanta University, Egypt
}

\begin{abstract}
The current research aims to identify the role of team sports curriculum and teachers in the acquisition of citizenship values for the third year female students (methods of teaching branch) of faculty of physical education. The researchers used the descriptive (survey) approach. Participants $(n=20)$ of this research were all faculty members responsible for teaching team sports curriculum (handball - basketball volleyball - field hockey) during the academic year 2014-2015. To collect data, the researchers used the following tools: A questionnaire about citizenship values that third year female students (methods of teaching branch) can acquire through the team sports curriculum and teachers (by the researchers) - Analysis of the team sports curriculum for third year female students (methods of teaching branch) - Teacher's observation form during teaching the curriculum to identify its effects on acquiring citizenship values. Results indicated that: There are some citizenship values included in team sports curriculum and this indicates that curriculum content is concerned with providing students with these values, Team sports teachers contributed explicitly and implicitly in providing some citizenship values during teaching.
\end{abstract}

\section{Key Words: Citizenship Values - Tritary Education - Team Sports}

\section{Introduction}

Our modern age is witnessing major advances in all fields of science and knowledge as this is the main characteristic of this age. Knowledge is increasing rapidly and this has direct and swift effects on various aspects of life including education. Modern man was separated from his society due to conflicts between himself and his ethical, social, and cultural values and the ways of fulfilling them. Educational policies indicate that the general aim of our educational curricula is to prepare the individual correctly to achieve happiness for himself and his society as well. AlSayed (1990) indicated that curriculum plays a major role in value transference and positive behavioral modification towards major issues of the Egyptian society as it is the first tool for educational institutes to achieve its objectives via a framework of interrelated concepts and organized activities that work on providing students skills, information, concepts and positive behaviors. This improves students' characters and develops them towards the benefits of individuals and the society.

The philosophy of designing physical education curricula relies greatly on explicit values in addition to implicit values that can only be identified through the thoughts supporting the curriculum or through methods and materials of teaching used by teachers. In other words, the content of physical education curricula, its programs, its teachers and its methods of teaching play a major role in improving and acquiring values and concepts in addition to modifying behaviors. 
Therefore, physical education helps greatly in preparing learners through its various activities related to their social life from the perspective of ethical ideals and citizenship values (Zaghloul \& Abu Harga, 1999).

Physical education curriculum plays the major role in acquiring these values through an interrelated framework of organized concepts. This provides students with a huge opportunity to improve their physical, mental, psychological, social and ethical aspects. In addition, these activities lead students to acquire such values through movement.

Team sports curriculum includes handball, basketball, volleyball and field hockey. These sports require several motor abilities and social, ethical and aesthetic values in addition to physical, muscular and mental abilities and team and individual skills. Content of any educational curriculum is the main part of it and its objectives should be fulfilled.( Bedair ,1985; Zaghloul \& Abu Harga,1999) indicated that curriculum content is of major importance for achieving curriculum objectives.

The physical education teacher should have a clear idea about his students' attitudes while teaching or while designing the curriculum so that he positively chooses the teaching materials and methods that make sense to learners and motivate them. In addition, teachers should work on forming their students' trends and attitudes that help them progress. Teachers should know that values included in physical education curricula rely on participation and experimentation. Therefore, the teacher is a value maker through various situations. $\mathrm{He}$ also represents the society directly. Therefore, he bears the responsibility of transferring these values to his students and maintaining them. He should never ignore his major role in forming learners' characters during their various stages and through various situations (Zaghloul, 2015).

The student's character is formed according to the teacher's effect on it. The teacher is the cornerstone for all educational situations. Team sports teachers are responsible for interpreting the society's values and behaviors in addition to the positive and negative aspects of students' interactions. Farid (1998) indicated that teachers should be enlightened, objective and productive as teaching in our age is more than a mere profession. Instead, a teacher should be an expert, an intelligent citizen and a humanistic activator who masters various skills and acquires knowledge and the ability to face social, political and cultural work for the benefit of the society.

Form main domains of values are identified. These include affiliation (patriotic - national and Islamic humanistic), rights (education - health and mental care - expression - equity dignified treatment - nomination and election), duties (time appreciation - work respect - preserving national unity respect for national symbols - patriotic defense) and social participation (Islamic values - mercy - justice - sincerity honesty). Sport is closely related to citizenship as citizenship education is not a curriculum to be taught. Instead, the teacher puts learners in educational situations through activities and frameworks to achieve citizenship through education.

Celebrating its $60^{\text {th }}$ anniversary, UNESCO issued (16) topics concerning citizenship and how it is acquired through physical activities. Citizenship education through team sports activities is seeking to improve knowledge and competencies that enable youth to improve their social abilities like teamwork, tolerance and sportsmanship in multi-cultural context in addition to creating balance between intellectual and physical activities. Citizenship is an intellectual framework 
including principles governing the relations between an individual and the democratic system in the society so that the individual's management of work is improved (Audigier, 2000).

Team sports curriculum in general, and each of its activities, includes explicit and implicit values. Implicit values can only be identified through the thoughts supporting the curriculum or through methods and materials of teaching used by teachers. Through their professional philosophy, teachers can transform values from mere slogans to actual behavioral patterns and social interactions. Their responsibilities are not limited to teaching things not related to educational aspects. Instead, they teach practices and translate them into behaviors to acquire values and relate them to the curriculum (Zaghloul,2015).

The researchers noticed a severe lack in citizenship studies like ( Mursy,2011; Khalil ,2010;Abd ElRazek,2008; $\quad$ Abd El-Naby,2006; Mohamed, 2006; Makroum, 2004; Ediger \& Marlow,1995). Therefore, it is necessary to identify citizenship values with all its four domains included in the team sports curriculum and how teachers introduce them to students of the third year (Methods of Teaching Brach). In addition, it is important to identify strengths to improve them and weaknesses to treat them so that the curriculum is supported by the desired knowledge and values. This is consistent with the notions that curricula should be analyzed according to the needs of educational development.

The current research problem deals with a major issue which is how to provide third year female students (Methods of Teaching Branch) with citizenship values through the team sports curriculum and teachers according to the major issues of the Egyptian society and the requirements of our modern age. This is because physical education in general, and team sports in specific, should play an educational role in serving the society. This research is of particular importance due to the following:

- The current research helps identifying citizenship values necessary for the third year female students (methods of teaching branch) of faculty of physical education according to their needs.

- The current research helps identifying the strengths and weaknesses of team sports curriculum to improve it and help students in their integrated development.

- The current research helps preparing the road for other researchers to identify the relations among values and principles of this stage and methods of teaching, teacher preparation and strategic aims of education.

- The current researcher contributes in preparing citizens with balanced characters who participate in building their nations and defending them in addition to practicing their rights and duties according to the constitution and laws and other explicit and implicit values of the curriculum.

- This topic is of major importance as it includes modern humanistic values in the age of globalization.

Aims:

The current research aims to identify the role of team sports curriculum and teachers in the acquisition of citizenship values for the third year female students (methods of teaching branch) of faculty of physical education. This requires the following:

a) To identify citizenship values that third year female students (methods of teaching branch) can acquire.

b) To analyze team sports curriculum for third year female students 
(methods of teaching branch) and to identify the availability of citizenship values in it .

c) To identify the role of team sports teachers in third year female students (methods of teaching branch) acquisition of citizenship values.

Research Questions:

a) What are citizenship values that third year female students (methods of teaching branch) can acquire?

b) How far citizenship values that third year female students (methods of teaching branch) can acquire are available in the team sports curriculum?

c) How far team sports teachers are involved in third year female students (methods of teaching branch) acquisition of citizenship values?

\section{Materials and Methods}

\section{Approach}

The researchers used the descriptive (survey) approach.

\section{Participants}

Participants $(n=20)$ of this research were all faculty members responsible for teaching team sports curriculum (handball - basketball - volleyball - field hockey) during the academic year 2014-2015.

\section{Measure}

- A questionnaire about citizenship values that third year female students (methods of teaching branch) can acquire through the team sports curriculum and teachers (by the researchers).

- Analysis of the team sports curriculum for third year female students (methods of teaching branch).

- Teacher's observation form during teaching the curriculum to identify its effects on acquiring citizenship values.

First: A questionnaire about citizenship values that third year female students (methods of teaching branch) can acquire through the team sports curriculum and teachers:

The researchers did not find a conclusive list for citizenship values required for students of this stage under investigation. Therefore, the researchers reviewed related literature and identified (20) values that can be acquired through team sports curriculum and its teachers. In addition, researcher's formulated procedural definitions for all values (annex 1) and presented them to (9) professors of curricula, methodology and team sports to show their opinions about them (annex 2). Experts' agreement percentage was $(100 \%)$. 
Table (1): Citizenship Values Required for Third Year female Students (Methods of Teaching Branch)

\section{Citizenship Values Procedural Definition}

A) Affiliation:

\begin{tabular}{|l|l} 
Patriotic Affiliation & Respecting others' rights in a safe life - Global Peace among
\end{tabular} nations - Islamic Virtues (empathy - justice - sincerity honesty)

Humanistic Affiliation $\quad$ Respecting others' rights in a safe life - appreciating others' cultures - believing in political freedom of every citizen Global Peace among nations

National and Islamic Affiliation

Islamic Virtues (empathy - justice - sincerity - honesty) Enlightened understanding of Islam - Arab and Islamic sense of belonging - Unifying relations among Arab nations

B) Rights:

Right for Education

Acquisition of knowledge and skills and using of modern technologies and legal fields - appreciating individual differences - improving sports talents

Right for Free Expression free expression about issues of concern - discussion during lectures to express ideas

Right for Equity equal treatment and equal services - justice in initiating activities

Right for Dignified Treatment

Right for Nomination and Election teacher's and administrators' respect for learners emotions and feelings - avoiding punishment

the right of a student to elect (and be elected) for positions like head of branch and students' committees

C) Duties:

Preserving public property

Respecting law and order

Preserving the environment

Appreciating time

Respecting work

Preserving national unity

Respecting Patriotic Figures

Patriotic Defense

Social Services

Respect for Others' performance

Positive role of the individual

Learning environment
Preserving the faculty's properties (fields - equipment) and maintaining damaged tools
Commitment to the study day and participation in order preserving committees

Participation in eco-preservation societies and activities in the faculty - planting trees in the campus

Performing assignments in time - good use of time

Involving in useful work and loving what you do Establishing the principle of public right in national wealth Saluting the flag sincerely - Respecting the national anthem Indicating what the country provides them of security and care like education and the duty of defending these things

D) Social Participation:

Encouraging students to discuss social issues - participation in preparing the upcoming lessons - participation in civil society associations (human rights)

Listening to others and speaking frankly with them - using discussion to resolve conflicts

Behaviors that make students avoid negative thoughts and encourage them to deal with others positively

The teacher as a model - democratic relations - mutual respect - caring for students' social issues 
This answers the first question " What are citizenship values that third year female students (methods of teaching branch) can acquire?"

\section{Second: Analysis of the team sports curriculum for third year female students to identify the availability of citizenship values:}

Curriculum analysis aims to identify the quantitative and qualitative aspects of the subject matter. The aim of analysis here is to describe and study the explicit content of team sports curriculum for the third year female students quantitatively and qualitatively to identify its strengths and weaknesses. The researchers analyzed the curriculum to know if it includes citizenship values students can acquire. They followed the following:

- Identifying citizenship values shown in table (1) as standardized values.

- Calculating analysis reliability.

- Calculating analysis validity.

\section{These aspects were treated as follows}

During the period from 8-10-2014 to 22-10-2014, the researchers read the content of team sports curriculum and each of its activities to identify the explicit and implicit values in it (according to the standardized values). Most of the time, values are formulated as words or descriptive phrases. Therefore, the researchers depended on word counts in this analysis. Through counting the frequency of each value, the researchers noticed that some values are not included in the curriculum.

\section{Validity of Analysis:}

According to results of analysis, consistency between researchers' results and assistants' results were calculated. Agreement between results reached (0.85). This indicates the validity of analysis as some values did not exist in the curriculum.

\section{Reliability of Analysis:}

To calculate reliability of analysis, analysis was repeated after two weeks and consistency percentage between the two analyses was calculated. This percentage reached (0.82) and proved reliability of analysis.

This answers the second question "How far citizenship values that third year female students (methods of teaching branch) can acquire are available in the team sports curriculum?"

Third: Teacher's observation form during teaching the curriculum to identify its effects on acquiring citizenship values

This form aims to collect data about real behavior of team sports teachers for the third year female students (methods of teaching branch) related to values under investigation. To design the form, researchers followed the following steps:

- Identifying values under investigation as shown in table (1) $(n=20)$

- Using 4-point likert scale as follows:

- 3 points: for direct inference of the value and relating it to teaching situation

- 2 points: for direct inference of the value without relating it to teaching situation.

- 1 point: for indirect inference of the value and relating it to teaching situation

- Zero: for lack of inference of the value.

- Experts' opinions about the form were identified and experts indicated the validity of the form. 
- The form was applied on a pilot study $(n=20)$ from the same research community and outside the main sample to validate the form. Observation was done on various lectures.

- To verify the form reliability, interobservers consistency was used. Observation was done for each of the pilot sample's members for one lecture. Number of agreements among members was calculated using the following equation:

Agreement percentage $=$ number of agreements / (number of agreements + number of disagreements) x 100

Reliability levels were established according to percentage of agreement. If values were less than (70\%) this indicates the low levels of reliability and if the percentage exceeded $(70 \%)$ this indicates high reliability. Percentage of agreement ranged between $88 \%$ and $92 \%$. This indicates the reliability of the form and this proved the validity of the final version for application.

\section{Main Application}

The Teacher's observation form was applied to the main sample from 26$11-2014$ to $17-12-2014$.

\section{Statistical Treatment}

The researchers used the following:

- Likert scale.

- Percentage.

\section{Results}

The researchers calculated the number of repetitions for each value included in the curriculum and the percentage of each value and its order according to the following equation: Percentage of each value $=$ (number of repetitions for each value / total number of repetitions) x 100 . 
Table (2): Frequencies and Percentages of Citizenship Values and their Order inside the Team Sports Curriculum for Third Year Female Students

\begin{tabular}{|c|c|c|c|c|c|c|c|c|c|c|c|c|}
\hline \multirow[b]{2}{*}{ N. } & \multicolumn{3}{|c|}{ Volleyball } & \multicolumn{3}{|c|}{ Basketball } & \multicolumn{3}{|c|}{ Handball } & \multicolumn{3}{|c|}{ Hockey } \\
\hline & $\mathbf{F}$ & $\%$ & $\begin{array}{c}\text { Orde } \\
\mathbf{r}\end{array}$ & $\mathbf{F}$ & $\%$ & $\begin{array}{c}\text { Orde } \\
\mathbf{r}\end{array}$ & $\mathbf{F}$ & $\%$ & $\begin{array}{c}\text { Orde } \\
\mathbf{r}\end{array}$ & $\mathbf{F}$ & $\%$ & $\begin{array}{c}\text { Orde } \\
\mathbf{r}\end{array}$ \\
\hline 1- & - & - & - & - & - & - & - & - & - & - & - & - \\
\hline 2- & - & - & - & - & - & - & - & - & - & - & - & - \\
\hline 3- & - & - & - & - & - & - & - & - & - & - & - & - \\
\hline 4- & 6 & 1.92 & 9 & 10 & 3.39 & 5 & 9 & 3.16 & 2 & 7 & 2.33 & 6 \\
\hline 5- & 9 & 2.95 & 6 & 14 & 4.75 & 2 & 12 & 4.21 & 1 & $\begin{array}{l}1 \\
0\end{array}$ & 3.33 & 3 \\
\hline 6- & 12 & 3.93 & 3 & 12 & 4.07 & 3 & 8 & 2.81 & 5 & 9 & 3.00 & 4 \\
\hline 7- & 10 & 3.28 & 5 & 8 & 2.71 & 7 & 7 & 2.46 & 6 & 9 & 3.00 & 4 \\
\hline 8- & 11 & 3.61 & 4 & 5 & 1.69 & 10 & 8 & 2.84 & 4 & 7 & 2.33 & 6 \\
\hline 9. & 3 & 0.98 & 12 & 4 & 1.36 & 11 & 3 & 1.05 & 10 & 6 & 2.00 & 7 \\
\hline $\begin{array}{l}10 \\
-\end{array}$ & 4 & 1.31 & 11 & 3 & 1.02 & 12 & 5 & 1.75 & 8 & 4 & 1.33 & 9 \\
\hline $\begin{array}{c}11 \\
-\end{array}$ & 9 & 2.95 & & 7 & 2.37 & 8 & 6 & 2.11 & 7 & 5 & 1.67 & 8 \\
\hline $\begin{array}{c}12 \\
-\end{array}$ & 8 & 2.62 & 7 & 11 & 3.73 & 4 & 11 & 3.86 & 2 & 9 & 3.00 & 4 \\
\hline $\begin{array}{c}13 \\
-\end{array}$ & 7 & 2.30 & 8 & 9 & 3.05 & 6 & 8 & 2.81 & 4 & $\begin{array}{l}1 \\
0\end{array}$ & 3.33 & 3 \\
\hline $\begin{array}{c}14 \\
-\end{array}$ & - & - & - & - & - & - & - & - & - & - & - & - \\
\hline $\begin{array}{c}15 \\
-\end{array}$ & - & - & - & - & - & - & - & - & - & - & - & - \\
\hline $\begin{array}{l}16 \\
-\end{array}$ & - & - & - & - & - & - & - & - & - & - & - & - \\
\hline $\begin{array}{c}17 \\
-\end{array}$ & 13 & 4.26 & 2 & 15 & 5.08 & 1 & 11 & 3.86 & 2 & $\begin{array}{l}1 \\
2\end{array}$ & 4.00 & 2 \\
\hline $\begin{array}{c}18 \\
-\end{array}$ & 15 & 4.92 & 1 & 11 & 3.73 & 4 & 12 & 4.26 & 1 & $\begin{array}{l}1 \\
4\end{array}$ & 4.67 & 1 \\
\hline $\begin{array}{c}19 \\
- \\
\end{array}$ & 2 & 0.66 & 13 & 6 & 2.02 & 9 & 5 & 1.75 & 8 & 2 & 0.67 & 11 \\
\hline $\begin{array}{c}20 \\
-\end{array}$ & 10. & 3.28 & 5 & 8 & 2.71 & 7 & 3 & 1.05 & 10 & 7 & 2.33 & 6 \\
\hline
\end{tabular}

Contribution of team sports teachers during teaching in acquiring citizenship values: 
Table (3): Relative Weight and Percentages of Team Sports Teachers on Citizenship

Values (n=20)

\begin{tabular}{|c|c|c|c|c|c|c|c|}
\hline $\mathbf{N}$. & Teaching Situation & $\begin{array}{l}\text { A direct } \\
\text { image of the } \\
\text { value and } \\
\text { relating it to } \\
\text { teaching } \\
\text { situation }\end{array}$ & $\begin{array}{l}\text { A direct } \\
\text { image of the } \\
\text { value } \\
\text { without } \\
\text { relating it to } \\
\text { teaching } \\
\text { situation }\end{array}$ & $\begin{array}{l}\text { An } \\
\text { indirect } \\
\text { image of } \\
\text { the value } \\
\text { during } \\
\text { teaching }\end{array}$ & $\begin{array}{c}\text { not } \\
\text { mentioning } \\
\text { the value }\end{array}$ & $\begin{array}{l}\text { relative } \\
\text { weight }\end{array}$ & $\begin{array}{l}\text { Percentage } \\
(\%)\end{array}$ \\
\hline 1- & Patriotic Affiliation & - & - & - & 20 & - & 100 \\
\hline 2- & Humanistic Affiliation & - & - & - & 20 & - & 100 \\
\hline 3- & $\begin{array}{c}\text { National and Islamic } \\
\text { Affiliation }\end{array}$ & - & 3 & - & 20 & - & 100 \\
\hline 4- & Right for Education & - & - & 11 & 9 & 11 & 18.33 \\
\hline 5- & $\begin{array}{l}\text { right for Free } \\
\text { Expression }\end{array}$ & - & - & 12 & 8 & 12 & 0.2 \\
\hline 6- & Right for Equity & - & - & 15 & 5 & 15 & 0.25 \\
\hline 7- & $\begin{array}{l}\text { Right for Dignified } \\
\text { Treatment }\end{array}$ & - & - & 13 & 7 & 13 & 21.67 \\
\hline 8- & $\begin{array}{l}\text { Right for Nomination } \\
\text { and Election }\end{array}$ & - & - & 8 & 12 & 8 & 13.33 \\
\hline 9- & $\begin{array}{l}\text { Preserving public } \\
\text { property }\end{array}$ & - & 4 & 18 & 8 & 16 & 26.67 \\
\hline 10- & $\begin{array}{l}\text { Respecting law and } \\
\text { order }\end{array}$ & - & - & 6 & 14 & 6 & 0.1 \\
\hline 11- & $\begin{array}{c}\text { Preserving the } \\
\text { environment }\end{array}$ & - & - & 8 & 12 & 8 & 13.33 \\
\hline 12- & Appreciating time & - & - & - & 14 & 6 & 0.1 \\
\hline 13- & Respecting work & - & - & 16 & 4 & 16 & 26.67 \\
\hline 14- & $\begin{array}{l}\text { Preserving national } \\
\text { unity }\end{array}$ & - & - & - & 20 & - & 100 \\
\hline 15- & $\begin{array}{c}\text { Respecting Patriotic } \\
\text { Figures }\end{array}$ & - & - & - & 20 & - & 100 \\
\hline 16- & Patriotic Defense & - & & & & & \\
\hline 17- & Social Services & - & - & 15 & 8 & 15 & 0.25 \\
\hline 18- & $\begin{array}{l}\text { Respect for Others' } \\
\text { performance }\end{array}$ & - & - & 20 & - & 20 & 33.33 \\
\hline 19- & $\begin{array}{l}\text { Positive role of the } \\
\text { individual }\end{array}$ & 6 & 2 & 7 & 5 & 29 & 48.33 \\
\hline 20- & $\begin{array}{c}\text { Learning } \\
\text { environment }\end{array}$ & - & - & 14 & 6 & 14 & 33.33 \\
\hline
\end{tabular}




\section{Discussion}

Concerning the first question, table (2) indicated that:

\section{For volleyball:}

Respect for others came first while social services came second, equity came third, nomination and election came fourth and dignified treatment and learning environment came fifth. Freedom of expression and preserving the environment came sixth, appreciation of time came seventh and work respect came eighth. Right for education came ninth, respecting laws came tenth, preserving public property came eleventh and positive role came twelfth. Volleyball curriculum included items indicating citizenship values as the highest percentage was $4.92 \%$ while the lowest percentage was $0.66 \%$. Values of patriotic affiliation, humanistic affiliation, national and Islamic affiliation, preserving national unity, respecting patriotic figures and national defense were not included in the curriculum.

\section{For basketball}

Social services came first followed by freedom of expression, equity, appreciation of time and respect for others, right for education, respect for work, dignified treatment and learning environment, preserving the environment, positive role of the individual, nomination and election, preserving public property, respect for laws respectively. Basketball curriculum included items indicating citizenship values as the highest percentage was $5.08 \%$ while the lowest percentage was $0.68 \%$. Values of patriotic affiliation, humanistic affiliation, national and Islamic affiliation, preserving national unity, respecting patriotic figures and national defense were not included in the curriculum.

\section{For handball}

Freedom of expression and respect for others came first followed by appreciation of time and social services, right for education and respect for patriotic figures, nomination and election and respect for work, humanistic affiliation and equity, dignified treatment and preserving national unity, preserving environment and national defense, respect for laws and positive role of the individual, patriotic affiliation, preserving public property and learning environment respectively. Handball curriculum included items indicating citizenship values as the highest percentage was $4.21 \%$ while the lowest percentage was $1.05 \%$. Values of national and Islamic affiliation, preserving national unity and respecting patriotic figures were not included in the curriculum.

\section{For field hockey}

Respect for others came first followed by social services, freedom of expression and respect for work, equity and dignified treatment, right for education and right for nomination and election and learning environment, preserving public property, preserving the environment, respect for laws, national defense and finally positive role the individual respectively. Field hockey curriculum included items indicating citizenship values as the highest percentage was $4.67 \%$ while the lowest percentage was $0.67 \%$. Values of patriotic affiliation, humanistic affiliation, national and Islamic affiliation, preserving national unity and respecting patriotic figures were not included in the curriculum.

This is consistent with (Fadel, 1990) who indicated that values provide life of individuals or groups with meaning. Humans always seek something and expend effort according to the importance and value of this thing. 
Farouk (1995) also indicated that negative aspects overcame positive ones in teachers' behaviors. These negative behaviors reflected on students and curriculum. This diminished the role of teacher in cultivating values.

Table (2) indicated that some values were explicitly seen in the curriculum while other values like patriotic affiliation, humanistic affiliation, national and Islamic affiliation, preserving national unity, respecting patriotic figures and national defense were not included in the curriculum. The researchers think that this is because team's sports curriculum is not consistent with other curricula that link subject matters with values. In addition, teachers of team sports are not interested in some citizenship values and how students can acquire them through the curriculum. This of course does not provide students with experiences to modify their behaviors towards their country. Zaghloul \& Abu Harga (2000) indicated that physical education curricula should include citizenship values and principles as these curricula are very effective in providing students with these values in addition to patriotic behaviors towards issues of the Egyptian society. It creates values and provides students with skills, information and positive behaviors required to enforce student's behavioral change and citizenship development.

This result is due to the weakness of team sports curriculum and this indicates that the curriculum needs to be amended so as to include values supporting patriotism, affiliation, religious pride, defense of rights, and understanding of duties and perception of political figures. This is consistent with (Shakeeb, 2000; Al-Seweedy, 2001).

Concerning the second question, table (3) the positive role of the individual came first while respect for others came second, respect for work and preserving public property came third, learning environment came fourth, dignified treatment came fifth, right for education came sixth, nomination and election came seventh, humanistic affiliation came eighth, equity and social services came ninth, freedom of expression came tenth and finally respect for laws and appreciation of time came eleventh. The highest value for teachers' contribution was $48.33 \%$ while the lowest value was $0.1 \%$.

Some citizenship values were not indicated during teaching from any of team sports teachers. This indicates that the educational role of team sports teachers during teaching is lacking. Of course, this decreases their important effect on acquiring these very important values. Zaghloul \& Abu Harga (1999) indicated that the educational role of physical education teacher is clear in spreading social, ethical, aesthetic and ecological values, concepts and activities. This is a continuous process not a temporary one. Abd Al-Kareem (1988) indicated that physical education teacher is among the most important educational personnel as he/she is the link between the existing behavior and the desired one.

The researchers think that the student is affected by both the teacher and the curriculum content. (Mursy,2011; Khalil ,2010; Abd El-Razek ,2008; Abd El-Naby ,2006; Mohamed ,2006; Makroum ,2004; Ediger \& Marlow ,1995) indicated the importance of teacher's role as he/she has the knowledge of physical activities, their methods of teaching and their approaches. He/she is responsible, to a great extent, for changing social values and behaviors through asserting positive and negative aspects of students' interactions. Zaghloul (1995) indicated that physical education teachers contribute in preparing good citizens and treating social issues. Physical education teachers study human nature in various situations and help students to understand themselves and their society. This answers the third question "How far team sports teachers are 
involved in third year female students (methods of teaching branch) acquisition of citizenship values?"

\section{Conclusions}

- There are some citizenship values included in team sports curriculum and this indicates that curriculum content is concerned with providing students with these values.

- Team sports teachers contributed explicitly and implicitly in providing some citizenship values during teaching.

\section{Recommendations}

- Students should acquire citizenship values and the desired behaviors

- Citizenship values should be a main consideration while developing curriculum content for team sports to contribute positively in students' acquisition of these important values

- Teams sports teachers should be trained on how to use all means to provide their students with citizenship values either explicitly or implicitly

- Student teachers should be aware of citizenship values in their behaviors and sayings

- Citizenship values and affiliation should be focused in general awareness as they should be developed

- Citizenship values should be a main focus for study whenever possible during team sports lessons 


\section{References}

Abd El-Kareem, Afaf (1988) Methods of Teaching Physical Education. Dar Al-Maaref, Alexandria - Egypt P: 33 (in Arabic)

Abd El-Razek, Afaf Mamdouh (2008) Developing some political values and citizenship rights for kindergarten children. Master thesis, Faculty of Education - Tanta University - Egypt (in Arabic)

Abu Al-Abbas, Rania Mursy (2011) Effects of a recreational program using folk and social games on affiliation and citizenship values for preschool children. Master Faculty of Physical Education - Tanta University - Egypt (in Arabic)

Al-Sayed, Ahmed Gaber (1990) Effectiveness of social studies curricula and teachers in developing social and ethical values for students of second stage of basic education. The Educational Journal, Vol.1, No. 6 P: 18, Faculty of Education - Sohag - Egypt (in Arabic)

Al-Seweedy, Gamal Sanad (2001) Towards a national strategy for developing citizenship and affiliation values. Paper presented to Seminar of Education and Citizenship. Faculty of Education - Bahrain P: 452 (in Arabic)

Audigier Fran Cois (2000).Basic concepts and core education for de maceration citizen ship / competencies for council of europ. stars bourse.p90

Ediger \& Marlow (1995) Astudy of values, Learning jihousev , 69 , No I , P.56-58, sep , U.S.A .

Fadel, Buthaina Mohamed (1990) Effects of sport on the value pattern of the character. PhD thesis, Faculty of Physical Education for Women Alexandria University - Egypt, P: 120 (in Arabic)

Farid, Kamel Mohamed (1998) Effects of a recommended program of physical education on improving ecological trends of students of faculties of physical education. PhD thesis, Ecological Studies and Research Institute, Ain Shams University - Cairo - Egypt, P: 141 (in Arabic)

Farouk, Ilham (1995) The role of elementary school in supporting ethical values of pupils. Master thesis, Faculty of Education - Helwan University - Egypt, P: 90 (in Arabic)

Khalil, Rasha Salah (2010) A Computer-assisted program of Motor Exploratory Activities and its effects on acquiring citizenship principle for students of first stage of basic education. Master thesis, Faculty of Physical Education - Tanta University - Egypt (in Arabic)

Makroum, Abd Al-Wadoud (2004) Expected contributions of tertiary education in improving citizenship values. Journal of Arab Education Future, Arab Center for Education and Development, Vol.10, No.33 (in Arabic) 
Musa, Sohair Badr (1985) Curricula of Physical Education. Dar Al-Maaref, Alexandria - Egypt. P: 25 (in Arabic)

Shakeeb, Shala (2000) Changing citizenship for children. Bahrain Forums P: 110 (in Arabic)

Tawfik, Mohamed Abd El-Naby (2006) The role of physical education curricula and teachers in providing secondary school students with ethical, social and aesthetic values in some Egyptian governorates. PhD Faculty of Physical Education - Tanta University - Egypt (in Arabic)

Zaghloul, Mohamed S. \& Abu Harga, Makarem H. (1999) Physical education curricula. Markaz Al-Ketab Press - Cairo - Egypt PP: 46, 88 (in Arabic

Zaghloul, Mohamed S. \& Abu Harga, Makarem H. (2002)Eco-physical education: Theory and Practice. Markaz Al-Ketab Press - Cairo Egypt P: 30 (in Arabic)

Zaghloul, Mohamed Saad (1995) The role of physical education curriculum in providing students with some ethical and social values during elementary schools in KSA. Scientific Journal of Physical Education and Sports, Vol. 8 P: 42. Faculty of Physical Education for Women Alexandria University - Egypt (in Arabic)

Zaghloul, Mohamed Saad (2015) Philosophical readings in physical education and its reflections on scholastic sport and teachers. Alam Al-Riada Press - Alexandria - Egypt PP: 65-66 (in Arabic) 